\title{
Warming Vistula River - the effects of climate and local conditions on water temperature in one of the largest rivers in Europe
}

\author{
Mariusz Ptak $^{1 *}$, Mariusz Sojka ${ }^{2}$, Renata Graf ${ }^{1}$, Adam Choiński ${ }^{1}$, Senlin Zhu ${ }^{3}$, Bogumił Nowak ${ }^{4}$ \\ ${ }^{1}$ Department of Hydrology and Water Management, Adam Mickiewicz University, B. Krygowskiego 10, 61-680 Poznań, Poland. \\ 2 Department of Land Improvement, Environmental Development and Spatial Management, Poznań University of Life Sciences, Piątkow- \\ ska 94E, 60-649 Poznań, Poland. \\ ${ }^{3}$ College of Hydraulic Science and Engineering, Yangzhou University, China. \\ ${ }^{4}$ Institute of Meteorology and Water Management - National Research Institute, Podleśna 61, 01-673 Warszawa, Poland. \\ * Corresponding author. E-mail: marp114@wp.pl
}

\begin{abstract}
The paper evaluates changes in the water temperature of the Vistula River - one of the longest rivers in Europe. Mean monthly and annual water temperatures from the period 1971-2017 for 11 stations along the entire length of the river revealed the increasing trends. The mean increase in water temperature in the analysed multi-annual period was $0.31{ }^{\circ} \mathrm{C} \mathrm{dec}-1$. In the majority of analysed stations, the key factor determining changes in the water temperature of the river was air temperature. The observed water warming in the Vistula River should be considered an exceptionally unfavourable situation in the context of importance of water temperature for a number of processes and phenomena occurring in river ecosystems. Given the scale of changes, fast measures should be undertaken to slow down the warming.
\end{abstract}

Keywords: Water temperature; Transit rivers; Trends; Transformation factors; Central Europe.

\section{INTRODUCTION}

One of the most serious problems currently faced by society is climate change, particularly manifested in intensification of extreme phenomena (Tomczyk, 2016; Tomczyk and Sulikowska, 2018). In reference to hydrological issues, a good indicator of extreme situations determined by climatic factors are processes observed in rivers, as evident among others through the occurrence of floods or water deficits (Arnell and Gosling 2016; Tomaszewski, 2007). The problem of transformations of river ecosystems is obviously substantially broader than only the commonly recognised cases, and concerns many physicochemical water parameters. One of them is temperature. Water temperature has a key importance for the course of biotic and abiotic processes (Ptak and Nowak, 2017). It shapes the optimal conditions of life and growth of organisms, and maintenance of the ecological function of rivers (Allan and Castillo, 2007; Caissie, 2006; Eby et al., 2014). Its increase can have serious consequences in changes of services of water ecosystems (Jackson et al., 2016; Letcher et al., 2016; Mohseni et al., 2003).

Research conducted in many regions around the globe revealed an increase in the temperature of river waters over the last century (O'Reilly et al., 2015; Webb and Nobilis, 2007; Williamson et al., 2019). According to the literature, considerable warming and a substantial increase in mean annual water temperatures at the end of the 1980's were a response to rapid climate change (Woolway et al., 2017; Zhang et al., 2014). Long-term temperature fluctuations of flowing waters also indicate the effects of the seasonality of the alimentation processes (Bates et al., 2008; Goulden et al., 2009), changes in the heat balance in the river channel (Caissie, 2006; Hannah et al., 2004), and changes in river valley management (Caissie et al., 2004; Langan et al., 2001; Webb et al., 2003). The research is conducted in different spatial locations and variable temporal scales with the application of genetic and statistical models. The models usually consider relationships of water temperature with climatic conditions, particularly air temperature (regression models and stochastic models), heat transfer at the river channel-water level (deterministic models), and effect of anthropogenic factors that disturb such relationships.

Climate change has already affected river water temperature in different parts of the globe, particularly in the temperate or cold zones (Kaushal et al., 2010; O'Reilly et al., 2015; van Vliet et al., 2013). In the period 1901-2001, an average recorded increase in global air temperature reached $0.6{ }^{\circ} \mathrm{C}$ (IPCC, 2018). Climate change forecasts assume further increase in air temperature, which may contribute to an increase in water temperature (on average by $0.8-1.6^{\circ} \mathrm{C}$ ), and changes in the thermalice regime (Caldwell et al., 2015; IPCC, 2018; Olsson et al., 2015; Taniwaki et al., 2017; van Vliet et al., 2013). According to the forecasts, the greatest increases in river water temperature will occur among others in Europe, where earlier research revealed its increase in a range of $1-3{ }^{\circ} \mathrm{C}$ (Arora et al., 2016; Basarin et al., 2016; Pekarova et al., 2008). The tendency for an increase in water temperature was also confirmed in the case of rivers in Poland, where the issues of thermal conditions of rivers represent an important trend of hydrological research (Graf, 2019; Graf and Wrzesiński, 2020; Łaszewski, 2020; Ptak, 2018).

Although the knowledge of changes in the water temperature of flowing waters is extensive, it still requires updating, particularly in reference to large, transit rivers of key importance. Such an approach is necessary, considering the elementary importance of water temperature for environmental as well as economic conditions.

The objective of the paper was to determine the long-term water temperature fluctuations in the Vistula River, one of the largest rivers in Europe, and the response of water temperature to climate change and regional and local factors disturbing such relations. In the case of transit rivers such as Vistula, where the patterns of discharge variability in the annual cycle are affected by the regime of its tributaries, and the delay in its alimentation due to the length of the river and size of its catchment, it is 
particularly important to understand the thermal behaviour of rivers and the related processes, to allow for an effective and sustainable management of the entire water ecosystem.

\section{MATERIALS AND METHODS Study objects}

The Vistula River, with a length of $1047 \mathrm{~km}$, is one of the longest rivers in Europe, and the longest river in the catchment of the Baltic Sea and in Poland (Figure 1). Vistula is a transit river, with springs at elevation above $1000 \mathrm{~m}$ a.s.l. on the western slope of Barania Góra in Beskid Śląski (the Carpathians). Its catchment area is $194424 \mathrm{~km}^{2}$ (the second largest in the Baltic Sea basin), and its mean discharge at the delta is $1080 \mathrm{~m}^{3} \mathrm{~s}^{-1}$. The hydrological regime shows features of pluvial-nival, nival-pluvial, and moderately developed nival regimes (Wrzesiński, 2013). Depending on the location of the observation station, the ice cover appears on the river on average in the first decade of January, and disappears on average in the third decade of February (Gołek, 1987; Pawłowski et al., 2017). The land use structure in the catchment is dominated by agricultural land $(66 \%)$, followed by forests (29\%) (Monitor Polski, 2011). Vistula constitutes fragments of two international waterways (E40 and E70), and is an important ecological corridor with north-south orientation (GackaGrzesikiewicz, 1995).

\section{Materials}

The analysis employed mean monthly and mean annual water temperatures in the Vistula River from the years 1971-2017 for 11 hydrological stations along the course of the river (Table 1, Figure 1). The analysis of the water temperature of the Vistula was conducted in reference to air temperature measured in 6 meteorological stations, and mean annual discharges measured in 8 hydrological stations (Table 1). The above data were provided by the Institute of Meteorology and Water Management - National Research Institute (IMGW-PIB). Water temperature was subject to daily point measurements at 6:00 UTC. The measurement was each time performed $0.4 \mathrm{~m}$ under the water surface - daily water level on the water gauge served as a reference point. The aforementioned data set permitted the calculation of mean monthly and mean annual water temperatures. All hydrological data are presented for hydrological years, beginning on 1 November of the preceding year, and lasting until 31 October of a given year.

Table 1. Description of measurement points: hydrological stations and climatic stations.

\begin{tabular}{|c|c|c|c|c|c|c|c|}
\hline No. & Name & Abbreviation & Data & $\mathrm{km}$ & No. & Name & Abbreviation \\
\hline 1 & Skoczów & Sk & WT, D & 35.75 & A & Bielsko Biała & $\mathrm{Bie}$ \\
\hline 2 & Goczałkowice & Go & WT, D & 69.92 & & & \\
\hline 3 & Szczucin & $\mathrm{Sz}$ & WT, D & 292.73 & B & Kraków & Kra \\
\hline 4 & Sandomierz & $\mathrm{Sa}$ & WT, D & 367.23 & $\mathrm{C}$ & Sandomierz & San \\
\hline 5 & Zawichost & $\mathrm{Za}$ & WT, D & 386.49 & & & \\
\hline 6 & Dęblin & De & WT, D & 487.76 & $\mathrm{D}$ & Warszawa & War \\
\hline 7 & Wyszogród & Wy & WT & 671.14 & & & \\
\hline 8 & Kępa Polska & $\mathrm{Ke}$ & WT, D & 690.14 & & & \\
\hline 9 & Toruń & To & WT, D & 815.08 & $\mathrm{E}$ & Toruń & Tor \\
\hline 10 & Chełmno & $\mathrm{Ch}$ & WT & 887.29 & & & \\
\hline 11 & Gdańsk & $\mathrm{Gd}$ & WT & 1011.75 & $\mathrm{~F}$ & $\mathrm{Hel}$ & Hel \\
\hline
\end{tabular}

WT- water temperature, D- discharge

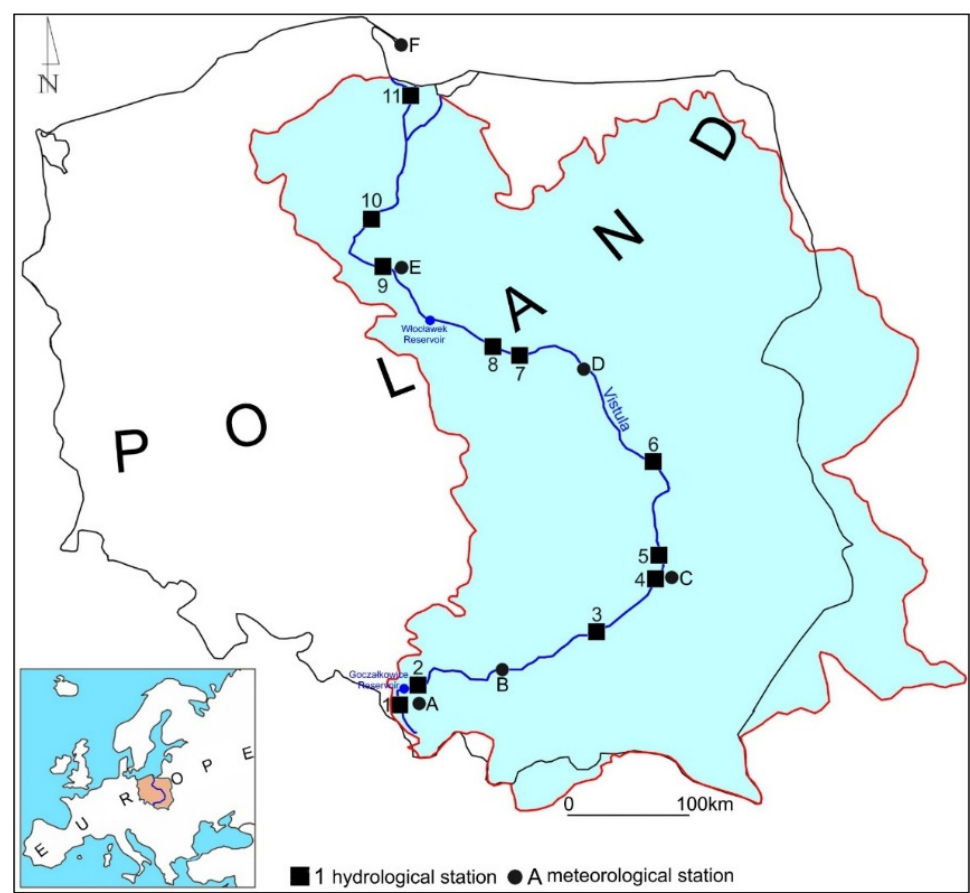

Fig. 1. Location of the river and measurement stations. Hydrological stations: 1- Skoczów, 2- Goczałkowice, 3- Szczucin, 4- Sandomierz, 5- Zawichost, 6- Dęblin, 7- Wyszogród, 8-Kępa-Polska, 9- Toruń, 10- Chełmno, 11- Gdańsk; Meteorological stations: A- Bielsko-Biała, B- Kraków, C- Sandomierz, D- Warszawa, E- Toruń, F- Hel. 


\section{Methods}

We have determined the trends over the study period, their magnitude, identified the break points in the data series and examined the relationships among the air temperature, river discharge and water temperature. The determination of tendencies of changes in the water temperature of the Vistula River involved the analysis of trends of changes by means of a nonparametric Mann-Kendall test (MK) (Kendall and Stuart, 1968). A zero hypothesis $\mathrm{H}_{0}$ was adopted, stating lack of a monotonic trend of mean monthly and mean annual water temperatures. The alternative hypothesis $\mathrm{H}_{1}$ assumed the existence of the trend. Testing hypotheses was based on the value of normalised statistic $Z$. The trend was assumed to be increasing when statistic $Z$ adopts a positive value, or decreasing when statistic $Z$ adopts a negative value. Normalised statistic $Z$ provided the basis for the calculation of test probability $p$ that allowed for verification whether changes in the water temperature in years were statistically significant or not. Values of changes in mean monthly and mean annual water temperatures in the Vistula River in the period 1971-2017 were calculated based on a non-parametric Sen test (Gilbert, 1987). The Sen test is less sensitive to the occurrence of extreme observations than the linear regression method in which equation parameters are calculated by means of the least squares method. In the Sen test, values of changes in mean monthly and mean annual temperatures can be described by means of a general formula $f(t)=$ $A t+B$, where $A$ is the searched for line gradient.

Gradient of line $A$ according to Sen is a median from the set $N$ of values $A \dot{t}$ that can be calculated based on the following formula:

$$
A= \begin{cases}A_{(N+1) / 2} & \text { if } N \text { is odd } \\ \frac{A_{N / 2}+A_{(N+2) / 2}}{2} & \text { if } N \text { is even }\end{cases}
$$

Values $A_{i}$ describe the slope of the line between two points of the time series of mean monthly or mean annual water temperatures, and can be calculated from the following formula:

$A_{i}=\frac{x_{j}-x_{k}}{j-k}, k \neq j$

For a time series composed of $n$ elements, $N=n(n-1) / 2$ of value $A_{i}$ exists.

Wild binary segmentation (WBS) methods developed by Fryzlewicz (2014) were used for change-point detection in the

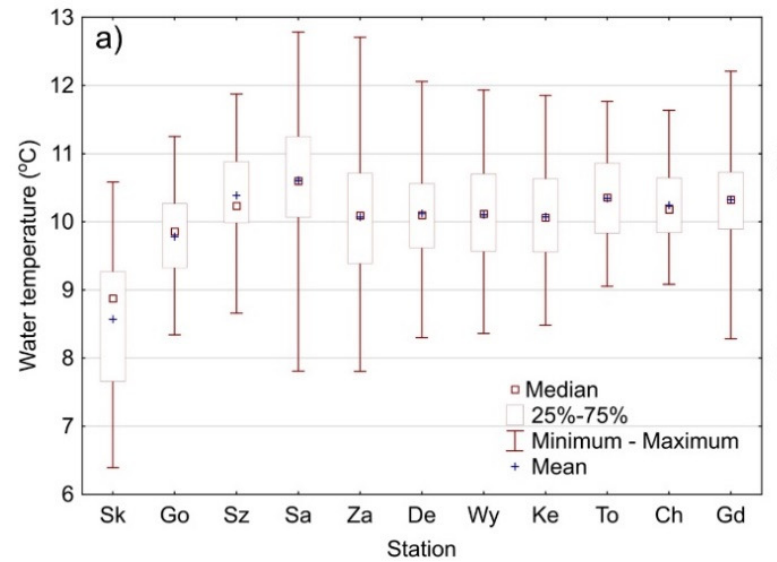

series of monthly and annual mean air temperatures. The WBS method is a modification of binary segmentation (BS) method.

In the WBS method, the exploration of change-point is performed at random intervals, based on CUSUM statistics. For the calculations, the wbs package developed by Baranowski and Fryzlewicz (2019) was used.

The analysis of changes in the water temperature in the Vistula River was performed in reference to changes in discharges and changes in air temperatures. For this purpose, annual data on air temperatures and discharges were analysed the same way, using Mann-Kendall and Sen test and WBS test. For the purpose of presentation, the relationships between water temperature, discharge and air temperature, a correlation analysis was performed employing the Spearman method.

Moreover, for the purpose of grouping hydrological and climatic stations by changes in water temperature, cluster analysis (CA) was performed. The cluster analysis was based on the Ward method, and square Euclidean distance was adopted as the probability measure. The division of stations into groups employed the threshold value of distance $D_{\text {Link }} D_{\text {Link.max }} \cdot 100 \%$ at a level of $66 \%$, and for the purpose of designation of subgroups, a threshold value at a level of $25 \%$ was adopted (Ptak et al., 2018). The cluster analysis was conducted based on results obtained from the Sen analysis, presented the magnitude of changes in mean monthly water and air temperatures in particular stations.

\section{RESULTS}

Mean annual water temperature in the Vistula River in period 1971-2017 varied from $8.6{ }^{\circ} \mathrm{C}$ (Sk) to $10.6{ }^{\circ} \mathrm{C}$ (Sa). The lowest mean annual temperature was observed in station $\mathrm{Sk}$ in $1978-6.4{ }^{\circ} \mathrm{C}$, and the highest in station Sa in $2016-12.6{ }^{\circ} \mathrm{C}$. Water temperature generally increased in the section between stations Sk and Sa. Then, in the section between stations Sa and $\mathrm{Za}$, the temperature decreased, that could have been the result of Vistula's alimentation along the section by its large tributary, namely the San River. From that point, the mean annual temperatures in Vistula varied between 10.1 and $10.3{ }^{\circ} \mathrm{C}$ (Figure 2a). The highest variability of mean annual water temperatures occurred in station $\mathrm{Sa}$, and the lowest in station $\mathrm{Ch}$. The analysis of mean monthly water temperatures in Vistula showed that the lowest temperatures were recorded in January, and the highest in July, reaching 1.2 and $20.1{ }^{\circ} \mathrm{C}$, respectively (mean of all stations). The lowest (January) and highest (July) variability of mean multiannual water temperatures between particular measurement stations also respectively occurs in these months (Figure $2 b$ ).

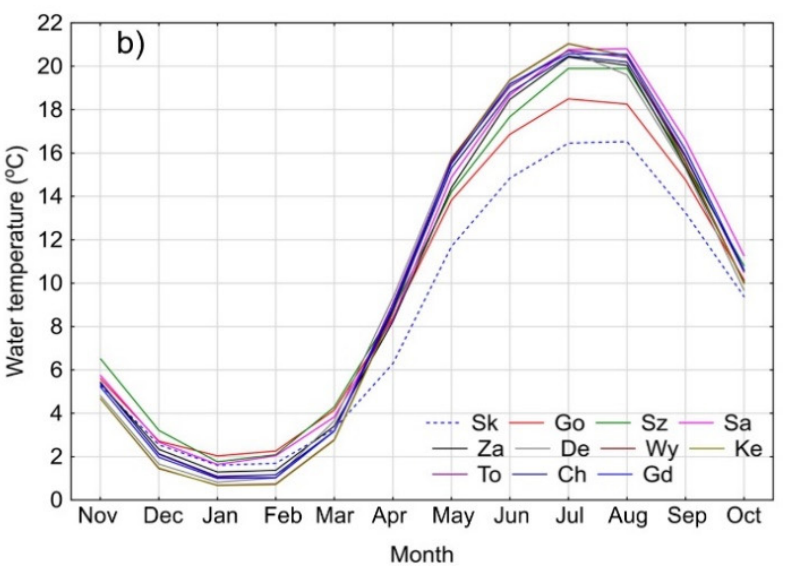

Fig. 2. Variability of mean annual (a) and mean monthly (b) water temperature in Vistula in particular stations. 
In a vast majority of cases, water temperature showed strong correlations with air temperature (correlation coefficients from 0.83 to 0.88 ). The correlation coefficients were lower in only three cases (Sz, Sa, Za), reaching $0.47,0.62$, and 0.40 , respectively. Moreover, correlations of water temperature with discharges were determined. As expected, the negative correlations of the two parameters were obtained. An exception was station Goczałkowice, where a positive correlation was found as a result of the inflow from the Goczałkowice reservoir (Figure 3).

Mean annual air temperature at particular meteorological station ranged from 8.2 to $8.5^{\circ} \mathrm{C}$, with extreme mean annual values from $6.2{ }^{\circ} \mathrm{C}$ in station $\mathrm{San}$ in 1996 to $10.4{ }^{\circ} \mathrm{C}$ in station Bie in 2007.

The long-term analysis for the period 1971-2017 showed that water temperature has an increasing trend at all the measurement points. On average for the entire river, an increase by $0.31{ }^{\circ} \mathrm{C} \mathrm{dec}^{-1}$ was recorded, with simultaneous variability of the rate of the process from $0.11^{\circ} \mathrm{C} \mathrm{dec}^{-1}(\mathrm{Sz})$ to $0.60{ }^{\circ} \mathrm{C} \mathrm{dec}^{-1}$ (Sk).

Only in two cases, $(\mathrm{Sz}, \mathrm{Za})$, the changes were not statistically significant $(\mathrm{p}=0.05)$. The air temperature over the same period was increasing as well by $0.3-0.39^{\circ} \mathrm{C} \mathrm{dec}^{-1}$ (Fig. 4).

The Wild Binary Segmentation (WBS) method (Fryzlewicz, 2014) revealed a maximum of two change points for air temperatures. They occurred at all meteorological stations in 1987 whereas an additional change point was detected for at Bie, Kra, San and War stations in 1997. A slightly more complicated situation occurs for water temperature where up to four change points were detected at individual hydrological stations. Apart from the change points occurring in 1987, the other ones were detected in the early 1980s (Go, Sa, Gd) and between 1995 and 1999 (Go, Sz, Sa, Za, De, Ke, To, Ch and Gd). Further change points were identified in 2006 and 2008 at hydrologic stations Sk, Sz, Wy, and Ke, and from 2011 to 2014 at stations Za, De, Wy, Ke, and Gd.

The analysis of monthly fluctuations of water temperature in the years 1971-2017 revealed its highest increase in July and lowest in February - by an average of 0.59 and $0.08^{\circ} \mathrm{C} \mathrm{dec}^{-1}$, respectively (Figure 5a). The lowest variability of changes in the water temperature between particular hydrological stations occurred in January, and the highest in April. The highest increase in water temperature generally occurred in station Sk. Only in August, September, and October, higher increases in water temperature were recorded in station Sa. In reference to mean monthly air temperatures, their highest increase occurred in April, averaging $0.71{ }^{\circ} \mathrm{C} \mathrm{dec}^{-1}$, and lowest in December, averaging $0.04{ }^{\circ} \mathrm{C} \mathrm{dec}^{-1}$ (Figure 5b).

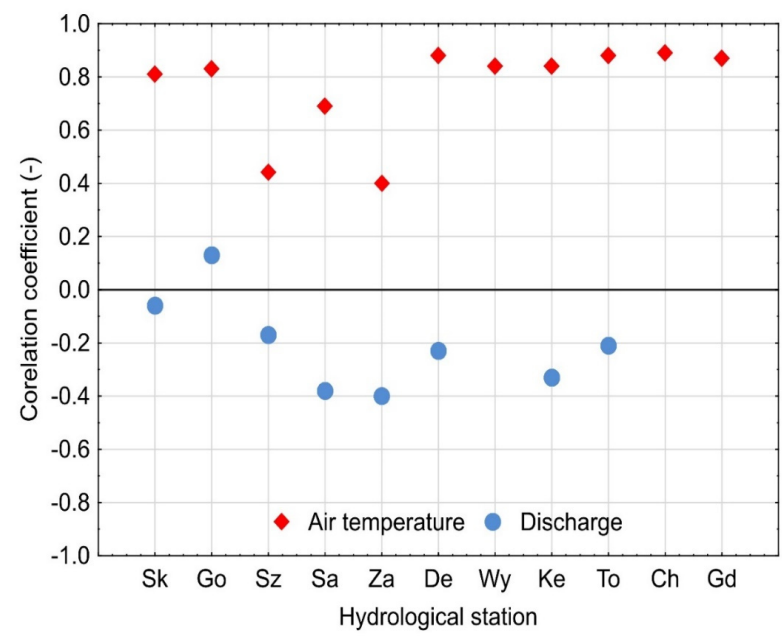

Fig. 3. Correlation between mean annual water temperatures and mean annual air temperatures and water discharges.
The spatial distribution of mean monthly water temperature and trends of its changes are presented in Figures 6 and 7.

As revealed by the images above, the lowest contrasts in the distribution of mean monthly temperatures and trends of their changes for particular sections of the Vistula River are recorded in the cold half-year, and the highest in the warm half-year. The highest variability of mean monthly water temperatures and trends is generally recorded in the upper course of the river. In the second case, station $\mathrm{Ch}$ stands out. In that station, an increase in water temperature is slower than in the two neighbouring stations. The aforementioned patterns are confirmed by grouping hydrological stations (Figure $8 \mathrm{a}$ ) in terms of magnitude of changes in monthly temperatures. Moreover, Figure $8 \mathrm{~b}$ presents similarity of the meteorological stations analysed in the paper, showing a distribution less complex than in the case of water.

\section{DISCUSSION}

The obtained results concerning trends and rate of changes in water temperature in the Vistula River are in accordance with other research regarding the issue (Bartholow, 2005; Graf and Wrzesiński, 2020; Kaushal et al., 2010; Magnuson et al., 2000; Marszelewski and Pius, 2016; Webb and Nobilis, 2007). The transformation of the water temperature of the largest river in Poland recorded over the recent decades results from the combined effect of climatic and regional factors. The close dependency of water temperature on air temperature is confirmed by among others high coefficients of determination obtained in the majority of studies (Caissie et al., 2001; Morrill et al., 2005; Pilgrim et al., 1998; Webb et al., 2003). Earlier research on thermal conditions of Polish rivers also confirmed a strong correlation with air temperature (Choiński et al., 2021; Łukaszewicz and Graf, 2020; Marszelewski and StrzyżewskaPietrucień, 2009). Graf and Wrzesiński (2020), investigating trends of water temperature in Polish rivers, generally determined no statistically significant changes in the winter season. It is worth emphasising that they did not find any statistically significant changes in the winter months in reference to air temperature either. Analyses conducted with the application of models including spline model functions also showed that the correlation of water temperature with air temperature is nonlinear, and mostly determined by the behaviour of water temperature during negative air temperature or in periods of longlasting frost (Graf, 2019; Łaszewski, 2014). Several decades of water temperature monitoring in the Vistula River shows that in the majority of the analysed stations, an evident change occurred at the end of the 1980's as a response to a change in the climate regime. Such a situation was confirmed in the case of other European rivers (Bonacci et al., 2008; Michel et al., 2020). Apart from climatic conditions, the remaining characteristics points of changes depend on changes in local factors, among others including groundwater supply.

As determined earlier (Figure 3), water temperature in Vistula shows weak and negative correlations with discharge in all (except for Go) of the analysed hydrological stations. Van Vliet et al. (2011) emphasise that during low flows, water temperature is the most sensitive to the effect of atmospheric conditions, and can reach high values. According to Arora et al. (2016), a decrease in water flow probably contributed to a faster increase in temperature in the river in summer and in the catchments of NE Europe (e.g. in the Łaba River catchment). In the case of the Ticino River (northern Italy), maximum water temperatures were determined to be correlated with low discharges recorded in the summer period (August) (Salmaso et 

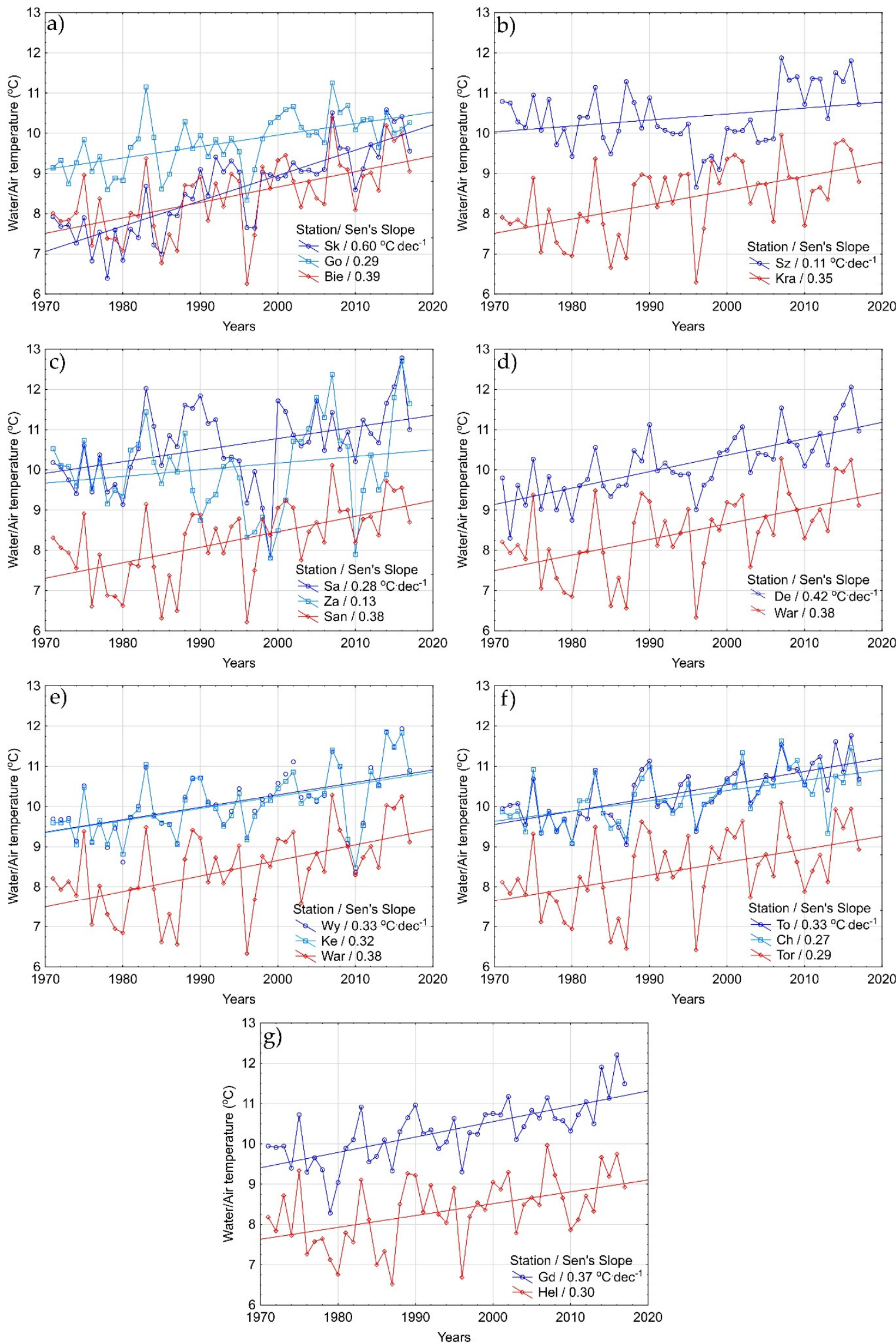

Fig. 4. Changes in mean annual water temperature (blue) in Vistula and air temperature (red) in the period 1971-2017.

al., 2017). Therefore, we assume that the highest overall increase in water temperature in the Vistula River in July was partially related also to the discharge that is generally smaller in this month. 

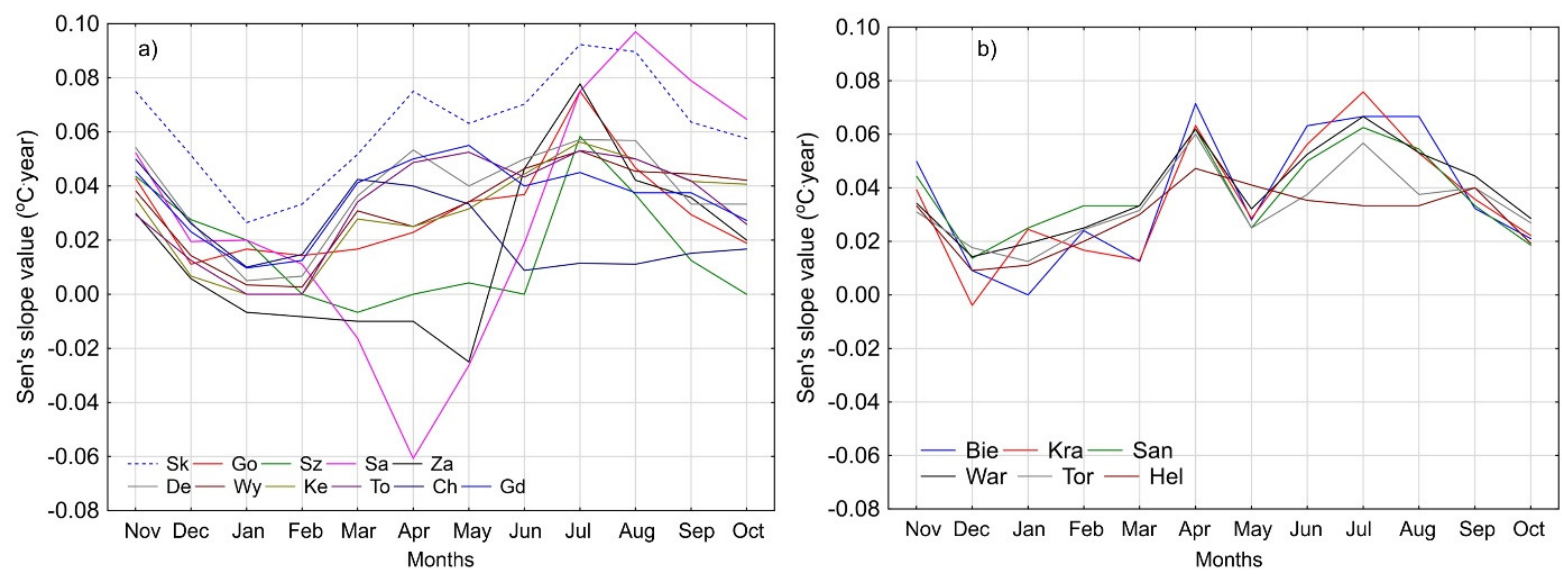

Fig. 5. Changes in mean monthly water temperatures in the Vistula River (a) and air temperatures (b) in the multi-annual period $1971-2017$.

Among 11 analysed stations along the entire course of the Vistula River, the lowest correlations with air temperature were recorded in three cases ( $\mathrm{Sz}, \mathrm{Sa}, \mathrm{Za})$. We assume that it should be associated with the importance of the effect of regional factors. According to Wrzesiński and Sobkowiak (2020), transformation of the hydrological regime of the Vistula River, observed in multi-annual and annual models, occurred on the entire length of the river, although the most frequent changes were determined in its upper course, based on the characteristics of discharges of its tributaries. In the transit section of Vistula, until Puławy, the river regime is shaped by its mountain tributaries carrying water from the Carpathians, and Vistula is characterised by a high variability of annual runoff here. It is evident in the components of the river's alimentation, according to Dynowska (1971) showing dominance of surface over groundwater supply in the section from the springs to the mouth of the San River.

Among the analysed cases, two more stations deserve particular attention, namely Skoczów - with water temperature considerably deviating from the remaining ones, and Chełmno, where water warming is lower in comparison to the station below and above this profile. Station Skoczów is the first measurement point downstream of the highest mountains in the Vistula River headwaters that feature high precipitation in summer relatively low evapotranspiration, and long winter season. The ice cover and snowmelt can largely determine thermal properties of the rivers in such conditions (MacDonald et al., 2014). Research by Cheval et al. (2014) concerning variability of selected climatic elements for the Carpathian region shows that snow cover decreased in reference to the study area. According to the latest research (Tomczyk et al., 2021), in the case of station Bielsko-Biała, a statistically significant decrease in days with snow cover was recorded - by an average of

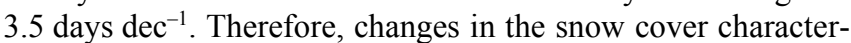
istics could also have an influence on the evident increase in water temperature at station Sk that was greater than at other stations. This situation corresponds with earlier studies conducted among others by Langan et. al. (2001) for Girnock burn, where the recorded increase in water temperature in the winter and spring season may result from an increase in air temperature that reduced the effect of snow and snowmelt in these periods. Similarly, for rivers in Scotland, Pohle et al. (2019) found that a smaller amount of snow and earlier melt season determine a decrease in its cooling properties in water temperature in spring.

Differences in terms of temperature in the case of station Chełmno towards two neighbouring stations, i.e. the ones below and above it, presumably result from the geomorphological and geological conditions. The Vistula River valley upstream of the water temperature monitoring site is extensive and incised deep into the bedrock, reaching a width of up to $9 \mathrm{~km}$. River valley here dissects the aquifer with a thickness reaching up to several dozen metres (Kozłowska and Kozłowski, 1988). The hydroisohypses suggest that Vistula is a gaining river in this section (Krawczyński, 2005). Intensive inflow of colder groundwaters contributes to the recorded lowest variability of mean annual temperatures and slower water warming in this profile in comparison to the neighbouring profiles. Similar effects were documented in many other studies. Research conducted in the USA (Silver Creek) shows that a decrease in discharge of groundwaters by $10 \%$ can cause an increase in mean water temperature by $0.3{ }^{\circ} \mathrm{C}$, and maximum temperature by $1.5{ }^{\circ} \mathrm{C}$ (Loinaz et al., 2013). In the case of the Aim River (France), Wawrzyniak et al. (2017) determined that when groundwater supply constitutes $16 \%$, it cools the river by 0.68 ${ }^{\circ} \mathrm{C}\left( \pm 0.13{ }^{\circ} \mathrm{C}\right.$, ) and when it accounts for only $2 \%$, it cools the river water by $0.11^{\circ} \mathrm{C}\left( \pm 0.01{ }^{\circ} \mathrm{C}\right)$. The analysis of the thermal regime of rivers in Latvia evidenced that lower water temperatures occurred in rivers with high groundwater supply (Latkovska and Apsite, 2016).

Compared to other large European rivers, the impact of hydrotechnical constructions on the regime of the Vistula River is relatively limited (Wrzesiński and Sobkowiak, 2020). The two largest dams are: Goczałkowice (reservoir volume 168 million $\mathrm{m}^{3}$ ) and Włocławek (reservoir volume 408 million $\mathrm{m}^{3}$ ). The correlations of water temperature in stations below both stations (Go and To) and air temperature (Bie and Tor) are strong, suggesting the dominant role of climatic factors. Hydrological station Goczałkowice is located in direct vicinity of the Goczałkowice reservoir. The observations conducted there by Ruman et al. (2013) documented the existence of ocassional thermal stratification in summer. However, the water temperature measurements carried out in period 2010 (June) 2013 (January) showed insignificant differences in the water temperature in Vistula above and below the reservoir $\left(10.7^{\circ} \mathrm{C}\right.$ and $11.0{ }^{\circ} \mathrm{C}$ on average, respectively). In the ${ }^{\circ} \mathrm{C}$ case of station Torun, i.e. the first of the stations analysed in the paper, located below the Włocławski reservoir, its potential effect on water temperature in this profile can be regarded low relative to the influence of air temperature due to the considerable distance $(58 \mathrm{~km})$. Another issue related to human pressure is the effect of energy production, that was the subject of many studies (e.g., Kajtazi and Floqi, 2021; Policht-Latawiec et al., 2016). In the case of Vistula, studies concluded that water temperature increased as a result of the inflow of waters from the power plant (Ciołkosz, 1975; Monitoring...2017). It should be 

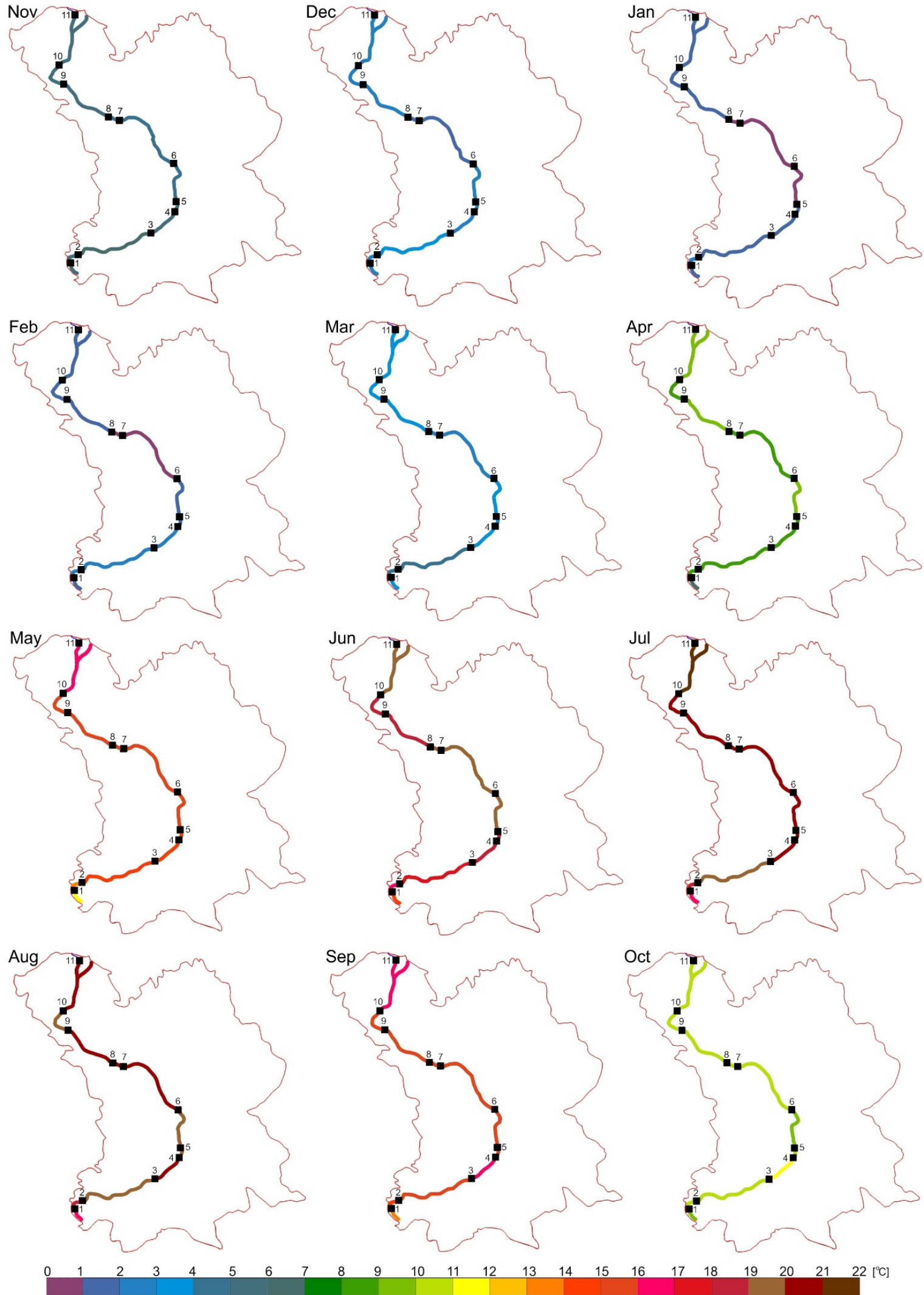

Fig. 6. Mean monthly water temperatures in the Vistula River in the period 1971-2017 - scale of a hydrological year.

emphasised, however, that the monitoring of thermal contamination was of a short-term character. Due to the lack of long-term data corresponding to the study period adopted in this paper, we do not discuss possible influence of energy production, volume of discharge of heated water, changes in the technological scope, etc.
As emphasised in the introduction, water temperature in the river is one of the basic parameters determining a number of phenomena, frequently with a cascade character. Therefore, the increase in water temperature recorded in the studied data series in all of the analysed stations should be considered unfavourable for the functioning of the ecosystem. 

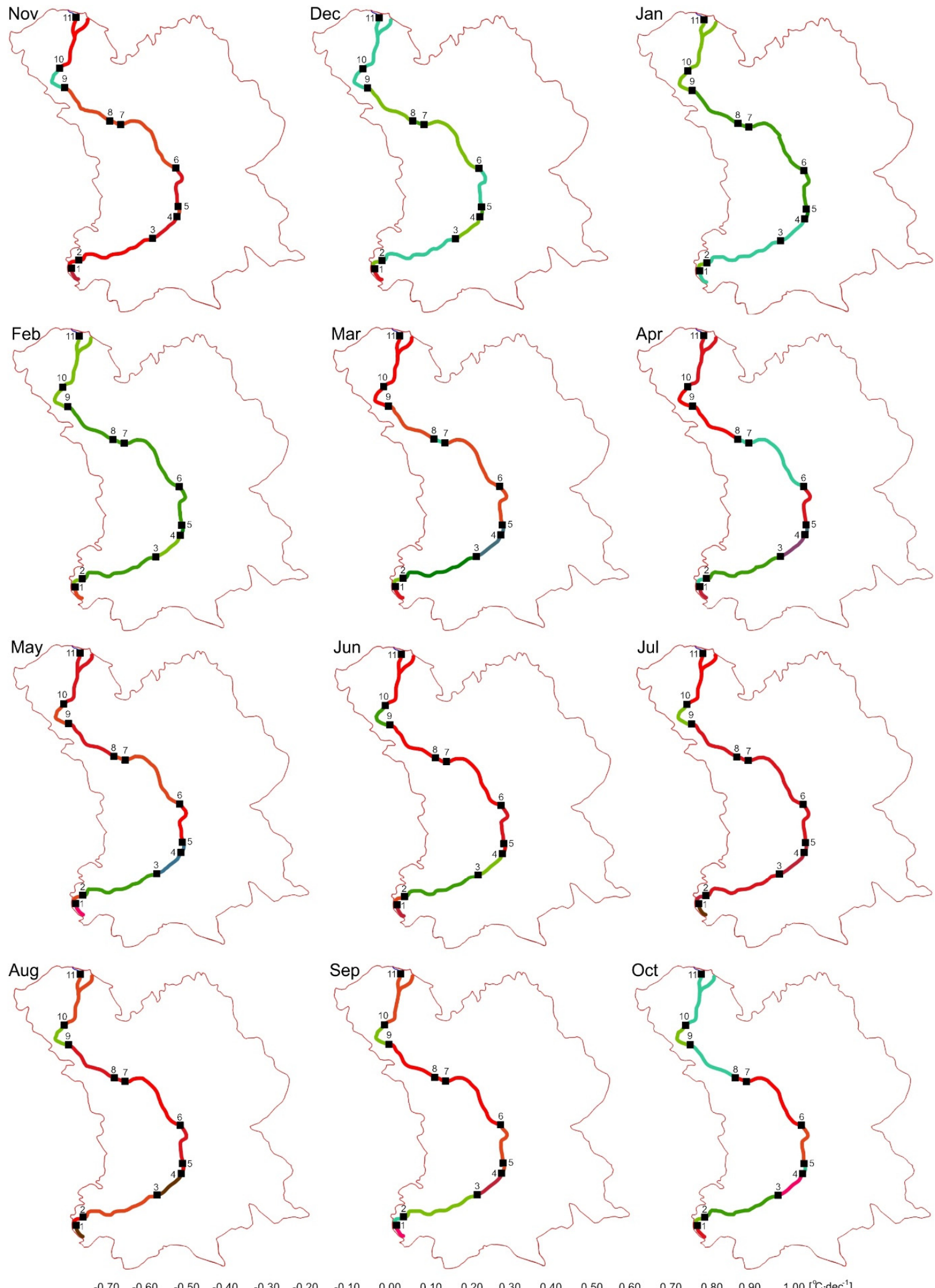

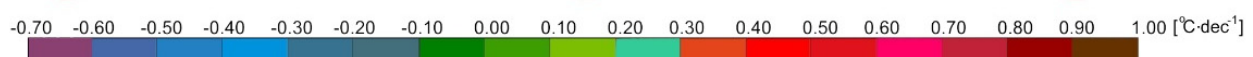

Fig. 7. Mean monthly trends of changes in water temperature in the Vistula River in the period 1971-2017 - scale of a hydrological year.

Water temperature increase with a simultaneous decrease in oxygen concentration contributes to the reduction of the water's self-cleaning properties (Ptak and Nowak, 2016). The issue is important in the context of use of waters of the Vistula River for economic purposes (provision of the population with drinkable water, irrigation, industry), as well as in reference to ac- tivities aimed at its protection against degradation. Dissolved oxygen concentration is the basic indicator of the state of water habitats, and its modelling is of key importance for the management of water quality in rivers (Stajkowski et al., 2020). Higher water temperature in a river, particularly in summer, also results in an increase in the amount of suspension of 

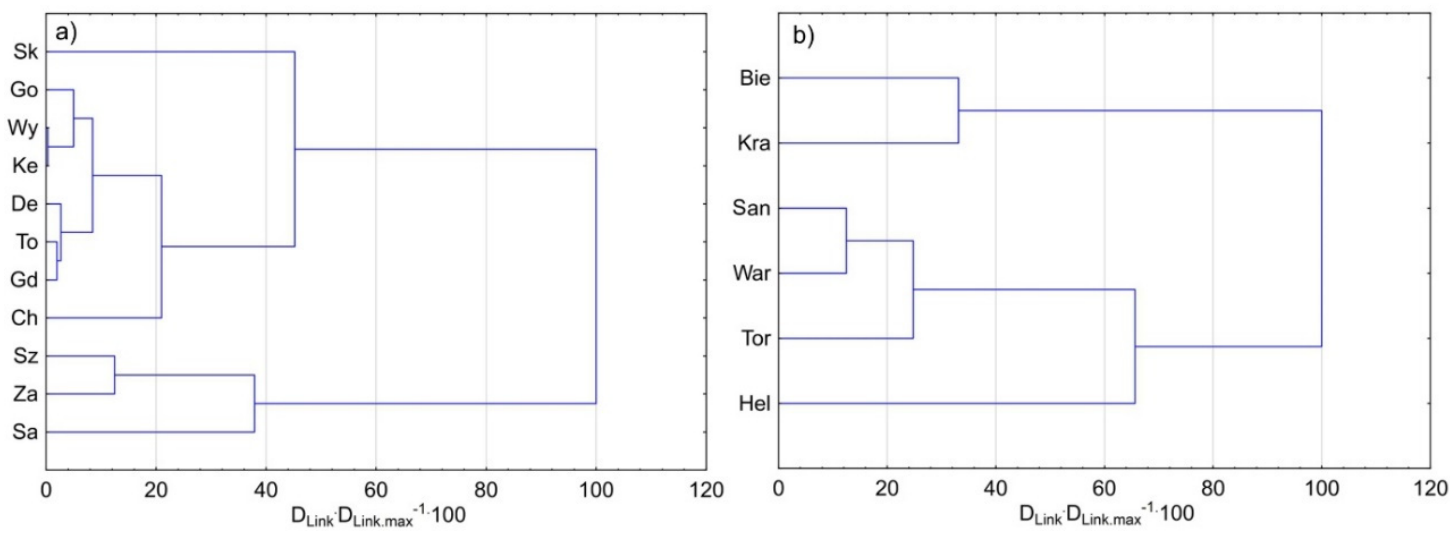

Fig. 8. Similarity of hydrological (a) and meteorological stations (b) in terms of magnitude of changes in monthly water and air temperatures in the period 1971-2017.

organic origin (Skolasińska and Nowak, 2018), leading to water turbidity, and therefore to worsening of the life conditions of many animals and plants inhabiting the river. According to predictions, water warming will continue in the future (Jones et al., 2017; Pedersen and Sand-Jensen, 2007; Šarauskiene et al., 2018; Soto, 2018). A fact that should be particularly disturbing for the agencies responsible for environmental management is that the greatest increase in water temperature (2070-2100) is predicted for Europe (next to several other regions, Van Vliet et al., 2013). As emphasised by Kaushal et al. (2010) further increase in water temperature can substantially contribute to eutrophication, biological productivity, metabolism, toxicity of contaminants, and a reduction of biodiversity. Therefore, in the case of the analysed river (and many others), the priority should be the development of a concept aimed at slowing down the effect of global warming on its thermal regime.

\section{CONCLUSIONS}

The presented paper analyses the evolution of water temperature in one of the longest rivers in Europe over the last almost five decades. The recorded increase in mean annual water temperature was not identical in all stations that is expected for the transit rivers. The air temperature was found to be the key factor responsible for the variability of water temperature in the Vistula River. The air temperature had weak correlations with water temperature in only three cases (out of 11). Factors disturbing the balance between air temperature and water temperature include among others: hydrological conditions, and low river discharge. The highest increase in water temperature was in July which is a month with generally smaller discharges. A possibly rapid action should be undertaken aimed at slowing down the unfavourable trend and attempt to preserve at least the current state of the river. The forecasted further changes in the water temperature can otherwise very soon contribute to many cascade responses in river ecosystems, limiting benefits resulting from their presence in the environment.

\section{REFERENCES}

Allan, J.D., Castillo, M.M., 2007. Stream Ecology: Structure and Function of Running Waters. 2nd Ed. Chapman and Hall, New York, USA.

Arnell, N.W., Gosling, S.N., 2016. The impacts of climate change on river flood risk at the global scale. Climatic Change, 134, 387-401.

Arora, R., Tockner, K., Venohr, M., 2016. Changing river temperatures in northern Germany: trends and drivers of change. Hydrological Processes, 30, 17, 3084-3096.

Baranowski, R., Fryzlewicz, P., 2019. Wild Binary Segmentation for Multiple Change-Point Detection. https://cran.rproject.org/web/packages/wbs/wbs.pdf. R package version 1.4.

Bartholow, J.M., 2005. Recent water temperature trends in the lower Klamath River, California. North American Journal of Fisheries Management, 25, 1, 152-162.

Basarin, B., Lukić, T., Pavić, D., Wilby, R.L., 2016. Trends and multi-annual variability of water temperatures in the river Danube, Serbia. Hydrological Processes, 30, 18, 3315.

Bates, B.C., Kundzewicz, Z.W., Wu, S., Palutikof, J.P., 2008. Climate Change and Water. Technical paper of the Intergovernmental Panel on Climate Change, IPCC Secretariat. Intergovernmental Panel on Climate Change, Geneva.

Bonacci, O., Trninić, D., Roje-Bonacci, T., 2008. Analysis of the water temperature regime of the Danube and its tributaries in Croatia. Hydrological Processes, 22, 7, 1014-1021.

Caissie, D., St-Hilaire, A., El-Jabi, N., 2004. Prediction of water temperatures using regression and stochastic models. In: Proceedings of the 57th Canadian Water Resources Association Annual Congress, Montreal, QC, Canada, 16-18 June 2004. Canadian Water Resources Association, Ottawa, ON, Canada.

Caissie, D., 2006. The thermal regime of rivers: a review. Freshwater Biology, 51, 1389-1406.

Caissie, D., El-Jabi N., Satish M.G., 2001. Modelling of maximum daily water temperatures in a small stream using air temperature. J. Hydrol., 251, 14-28.

Caldwell, P., Segura, C., Laird, S.G., Sun, G., McNulty, S.G., Sandercock, M., Boggs, J., Vose, J.M., 2015. Short-term stream water temperature observations permit rapid assessment of potential climate change impacts. Hydrological Processes, 29, 2196-2211.

Cheval, S., Birsan, M.-V., Dumitrescu, A., 2014. Climate variability in the Carpathian Mountains Region over 1961-2010. Global and Planetary Change, 118, 85-96.

Choiński, A., Ptak, M., Volchak, A., Kirvel, I., Valiuškevičius, G., Parfomuk, S., Kirvel, P., Sidak, S., 2021. Effect of air temperature increase on changes in thermal regime of the Oder and Neman rivers flowing into the Baltic Sea. Atmosphere, 12, 498, 1-15.

Ciołkosz, A., 1975. Zastosowanie długofalowego promieniowania podczerwonego $\mathrm{w}$ badaniach termalnego zanieczyszczenia rzek. Prace Instytutu Geodezji i Kartografii, 22, 2, $51,29-73$.

Dynowska, I., 1971. Typy reżimów rzecznych w Polsce. Zesz. Nauk. UJ, Prace Geograficzne, 28.

Eby, L., Helmy, O., Holsinger, L.M., Young, M.K., 2014. 
Evidence of climate-induced range contractions in bull trout salvelinus confluentus in a rocky mountain watershed, USA. PLoS ONE, 9, e98812.

Fryzlewicz, P., 2014. Wild binary segmentation for multiple change-point detection. Annals of Statistics, 42, 6, 22432281.

Gacka-Grzesikiewicz, E. (Ed.) 1995. Korytarz ekologiczny doliny Wisły. Stan - Funkcjonowanie-Zagrożenia. Fundacja IUCN Poland, Warszawa. http://fs.siteor.com/bocian/files/ www/biblioteka/ksiazki/korytarz_ekologiczny_doliny_wisly .pdf?1292203248 (accessed on 10.01.2021).

Gilbert, R.O., 1987. Statistical Methods for Environmental Pollution Monitoring. Van Nostrand Reinhold Co., New York, NY, USA, 320 .

Gołek, J., 1987. Zjawiska lodowe na rzekach i jeziorach. In: Atlas hydrologiczny Polski. IMiGW, Wyd. Geol, Warszawa.

Goulden, M., Conway, D., Persechino, A., 2009. Adaptation to climate change in international river basins in Africa. Hydrological Sciences Journal, 54, 805-828.

Graf, R., 2019. A multifaceted analysis of the relationship between daily temperature of river water and air. Acta Geophysica, 67, 905-920.

Graf, R., Wrzesiński, D., 2020. Detecting patterns of changes in river water temperature in Poland. Water, 12, 5, 1327.

Hannah, D.M., Malcolm, I.A., Soulsby, C., Youngson, A.F., 2004. Heat exchanges and temperatures within a salmon spawning stream in the Cairngorms, Scotland: Seasonal and subseasonal dynamics. River Research and Applications, 20, 635-652.

IPCC, 2018. SRCCL. Climate Change and Land. IPCC Special Report on Climate Change, Desertification, Land Degradation, Sustainable Land Management, Food Security, and Greenhouse gas fluxes in Terrestrial Ecosystems. Summary for Policymakers. Available online: https://www.ipcc.ch/site/assets/uploads /2019/08/4.-SPM_Approved_Microsite_FINAL.pdf (accessed on 10.01.2021).

Jackson, M.C., Loewen, C.J.G., Vinebrooke, R.D., Chimimba, C.T., 2016. Net effects of multiple stressors in freshwater ecosystems: A meta-analysis. Glob. Chang. Biol., 22, 180-189.

Jones, L.A., Muhlfeld, C.C., Marshall, L.A., 2017. Projected warming portends seasonal shifts of stream temperatures in the Crown of the Continent Ecosystem, USA and Canada. Climatic Change, 144, 4, 641-655.

Kajtazi, B.S., Floqi, T., 2021. Thermo Power Plant "Kosovo B"-A pollution source for Sitnica River. European Journal of Engineering and Technology, 6, 3.

Kaushal, S.S., G.E. Likens, N.A. Jaworski, M.L., Pace, A.M., Sides, D., Seekell, K.T., Belt, D.H., Secor, Wingate, R.L., 2010. Rising stream and river temperatures in the United States. Frontiers in Ecology and the Environment, 8, 461-466.

Kendall, M.G., Stuart, A., 1968. The Advanced Theory of Statistics, 3. Charles Griffin Ltd., London, UK.

Kozłowska, M., Kozłowski, I., 1988. Szczegółowa Mapa Geologiczna Polski 1:50000, 281- Arkusz Unisław. Wydawnictwa Geologiczne, Warszawa.

Krawczyński, J., 2005. Baza danych GIS Mapy Hydrogeologicznej Polski 1:50000, 281- Unisław (N-34-97-B). Pierwszy poziom wodonośny. Występowanie i hydrodynamika. PIG\&MŚ, Warszawa.

Langan, S.J., Johnston, L., Donaghy, M.J., Youngson, A.F., Hay, D.W., Soulsby, C., 2001. Variation in river water temperatures in an upland stream over a 30 -year period. Science of the Total Environment, 265, 195-207.

Latkovska, I., Apsite, E., 2016. Long-term changes in the water temperature of rivers in Latvia. Proceedings of the Latvian
Academy of Sciences, Section B: Natural, Exact, and Applied Sciences, 70, 2, 78-87.

Langan. S.J, Johnston, L., Donaghy, M.J., Youngson, A.F., Hay, D.W., Soulsby, C., 2001. Variation in river water temperatures in an upland stream over a 30 -year period. Science of the Total Environment, 265, 195-207.

Letcher, B.H., Hocking, D.J., O’Neil, K., Whiteley, A.R., Nislow, K.H., O’Donnel, M.J., 2016. A hierarchical model of daily stream temperature using air-water temperature synchronization, autocorrelation, and time lags. Peer J., 4, e1727.

Loinaz, M.C., Davidsen, H.K., Butts, M., Bauer-Gottwein, P., 2013. Integrated flow and temperature modeling at the catchment scale. Journal of Hydrology, 495, 238-251.

Łaszewski, M., 2014. Metody określania związków temperatury wody rzecznej i temperatury powietrza na przykładzie rzeki Świder. Prace Geograficzne, 136, 45-60.

Łaszewski, M.A., 2020. The effect of environmental drivers on summer spatial variability of water temperature in Polish lowland watercourses. Environmental Earth Sciences, 79, 244.

Łukaszewicz, J., Graf, R., 2020. The variability of ice phenomena on the rivers of the Baltic coastal zone in the Northern Poland. Journal of Hydrology and Hydromechanics, 68, 38-50.

MacDonald, R.J., Boon, S., Byrne, J.M., 2014. A process-based stream temperature modelling approach for mountain regions. Journal of Hydrology, 511, 920-931.

Magnuson, J.J., Robertson, D.M., Benson, B.J., Wynne, R.H., Livingstone, D.M., Arai, T., Assel, R.A., Barry, R.G., Card, V., Kuusisto, E., et al. 2000. Historical trends in lake and river ice cover in the Northern Hemisphere. Science, 289, 1743-1746.

Marszelewski, W., Strzyżewska-Pietrucień, I., 2009, Temperatura wody dolnej Wisły i jej wieloletnie zmiany. In: Jankowski, A.T., Absalon, D., Machowski, R., Ruman, M. (Eds.): Przeobrażenia stosunków wodnych w warunkach zmieniającego się środowiska. Wydział Nauk o Ziemi Uniwersytetu Śląskiego, Sosnowiec, pp. 197-209.

Marszelewski, W., Pius, B., 2016. Long-term changes in temperature of river waters in the transitional zone of the temperate climate: a case study of Polish rivers. Hydrological Sciences Journal, 61, 8, 1430-1442.

Michel, A., Brauchli, T., Lehning, M., Schaefli, B., Huwald, H., 2020. Stream temperature and discharge evolution in Switzerland over the last 50 years: annual and seasonal behaviour. Hydrology and Earth System Sciences, 24, 1, 115-142.

Mohseni, O., Stefan H.G., Eaton, J.G., 2003. Global warming and potential changes in fish habitat in U.S. streams. Climate Change, 59, 389-409.

Monitor Polski, 2017. Monitoring zanieczyszczenia termicznego zrzutu ciepłej wody z Elektrowni Połaniecprzepływ niski/średni, Zakład Badań Ekologicznych, Kraków, 49, 549.

Morrill, J.C., Bales, R.C., Conklin, M.H., 2005. Estimating stream temperature from air temperature: Implications for future water quality. Journal of Environmental Engineering, 131, 1, 139-146.

Olsson, T., Jakkila, J., Veijalainen, N., Backman, L., Kaurola, J., Vehviläinen, B., 2015. Impacts of climate change on temperature, precipitation and hydrology in Finland - studies using bias corrected regional climate model data. Hydrology and Earth System Sciences, 19, 3217-3238.

O'Reilly, C.M., Sharma, S., Gray, D.K., Hampton, S.E., Read, J.S., et al., 2015. Rapid and highly variable warming of lake surface waters around the globe. Geophysical Research Letters, 42, 10773-10781. 
Pawłowski, B., Gorączko, M., Szczerbińska, A., 2017. Zjawiska lodowe na rzekach w Polsce. In: Jokiel, P., Marszelewski, W., Pociask-Karteczka, J. (Eds.): Hydrologia Polski. Wydawnictwo Naukowe PWN, Warszawa, Poland, pp. 195-200.

Pedersen, N.L., Sand-Jensen, K., 2007. Temperature in lowland Danish streams: Contemporary patterns, empirical models and future scenarios. Hydrological Processes, 21, 3, 348-358.

Pekarova, P., Halmova, D., Miklanek, P., Onderka, M., Pekar, J., Skoda, P., 2008. Is the water temperature of the Danube River at Bratislava, Slovakia, rising? Journal of Hydrometeorology, 9, 5, 1115-1122.

Pilgrim, J.M., Fang, X., Stefan, H.G., 1998. Stream temperature correlations with air temperatures in Minnesota: implications for climate warming. Journal of the American Water Resources Association, 34, 5, 1109-1121.

Pohle, I., Helliwell, R., Aube, C., Gibbs, S., Spencer, M., Spezia, L., 2019. Citizen science evidence from the past century shows that Scottish rivers are warming. Science of the Total Environment, 659, 53-65.

Policht-Latawiec, A., Kanownik, W., Jurek, A., 2016. The effect of cooling water discharge from the power station on the quality of the Skawinka River water. Carpathian Journal of Earth and Environmental Sciences, 11, 2, 427-435.

Ptak, M., Nowak, B., 2016. Variability of oxygen-thermal conditions in selected lakes in Poland. Ecological Chemistry and Engineering S, 23,4, 639-650.

Ptak, M., Nowak, B., 2017. Zmiany temperatury wody w Prośnie w latach 1965-2014, Woda-Środowisko-Obszary Wiejskie, 17, 3, 101-112.

Ptak, M., 2018. Long-term temperature fluctuations in rivers of the Fore-Sudetic region in Poland. Geografie, 123, 3, 279 294.

Ptak, M., Sojka, M., Choiński, A., Nowak, B. 2018. Effect of environmental conditions and morphometric parameters on surface water temperature in Polish lakes. Water, 10, 580.

Ruman, M., Absalon, D., Matysik, M., 2013. Innowacyjne rozwiązania w monitoringu jakości wód powierzchniowych. Ekoinnowacje w ochronie środowiska 2013, pp. 72-82.

Salmaso, F., Quadroni, S., Gentili, G., Crosa, G., 2017. Thermal regime of a highly regulated Italian River (Ticino River) and implications for aquatic communities. Journal of Limnology, 76, 1, 23-33.

Skolasińska, K., Nowak, B., 2018. What factors affect the suspended sediment concentrations in rivers? A study of the upper Warta River (Central Poland). River Research and Applications 34,2, 112-123.

Soto, B., 2018. Climate-induced changes in river water temperature in North Iberian Peninsula. Theoretical and Applied Climatology, 133, 1-2, 101-112.

Stajkowski, S., Zeynoddin, M., Farghaly, H., Gharabaghi, B., Bonakdari, H., 2020 A methodology for forecasting dissolved oxygen in urban streams. Water, 12, 9, Article number: 2568 .

Šarauskiene, D., Akstinas, V., Kriaučiūniene, J., Jakimavičius, D., Bukantis, A., Kažys, J., Povilaitis, A., Ložys, L.,
Kesminas, V., Virbickas, T., Pliuraite, V., 2018. Projection of Lithuanian river runoff, temperature and their extremes under climate change. Hydrology Research, 49, 2, 344-362.

Taniwaki, R.H., Piggott, J.J., Ferraz, S.F., Matthaei, C.D., 2017. Climate change and multiple stressors in small tropical streams. Hydrobiologia, 793, 41-53.

Tomaszewski, E. 2007. Hydrological droughts in central Poland - temporal and spatial patterns. Geographia Polonica, 80, 2, 117-123.

Tomczyk, A.M., 2016. Impact of atmospheric circulation on the occurrence of heat waves in southeastern Europe. Időjárás, 120, 4, 395-414.

Tomczyk, A.M., Sulikowska, A., 2018. Heat waves in lowland Germany and their circulation-related conditions. Meteorology and Atmospheric Physics, 130, 5, 499-515.

Tomczyk, A., Bednorz, E., Szyga-Pluta, K., 2021. Changes in air temperature and snow cover in winter in Poland. Atmosphere, 12, 1, 68 .

Van Vliet, M.T.H., Ludwig, F., Zwolsman, J.J.G., Weedon, G.P., Kabat, P., 2011. Global river temperatures and sensitivity to atmospheric warming and changes in river flow. Water Resources Research, 47, 2, Article number: W02544.

Van Vliet, M.T.H., Franssen, W.H.P., Yearsley, J.R., Ludwig, F., Haddeland, I., Lettenmaier, D.P., Kabat, P., 2013. Global river discharge and water temperature under climate change. Global Environmental Change, 23, 2, 450-464.

Wawrzyniak, V., Allemand, P., Bailly, S., Lejot, J., Piégay, H., 2017. Coupling LiDAR and thermal imagery to model the effects of riparian vegetation shade and groundwater inputs on summer river temperature. Science of the Total Environment, 592, 616-626.

Webb, B.W., Clack, P.D., Walling, D.E. 2003. Water $\square$ air temperature relationships in a Devon river system and the role of flow. Hydrological Processes, 17, 15, 3069- 3084.

Webb, B.W., Nobilis, F., 2007. Long-term changes in river temperature and the influence of climatic and hydrological factors. Hydrological Sciences Journal, 52, 74-85.

Williamson, R.J., Entwistle, N.S., Collins, D.N., 2019. Meltwater temperature in streams draining Alpine glaciers. Science of The Total Environment, 658, 777-786.

Woolway, R.I., Dokulil, M.T., Marszelewski, W., Schmid, M., Bouffard, D., Merchant, C.J., 2017. Warming of Central European lakes and their response to the 1980 s climate regime shift. Climatic Change, 142, 3-4, 505-520.

Wrzesiński, D., 2013. Entropy of River Flows in Poland. Bogucki, Poznań.

Wrzesiński, D., Sobkowiak, L., 2020. Transformation of the flow regime of a large allochthonous river in Central Europe - An example of the Vistula River in Poland. Water, 12, 2, 507.

Zhang, X.J., Tang, Q.H., Pan, M. et al., 2014. A long-term land surface hydrologic fluxes and states dataset for China. Journal of Hydrometeorology, 15, 2067-2084.

Received 1 March 2021 Accepted 18 July 2021 